\title{
PUBLIC ADMINISTRATION \\ OF THE NATIONAL BANKING SYSTEM OF UKRAINE \\ IN THE GLOBAL SPACE OF THE FUTURE
}

\section{ПУБЛІЧНЕ УПРАВЛІННЯ \\ НАЦІОНАЛЬНОЮ БАНКІВСЬКОЮ СИСТЕМОЮ УКРАЇНИ У ГЛОБАЛЬНОМУ ПРОСТОРІ МАЙБУТНЬОГО}

\section{Marianenko Gennadiy ${ }^{1}$}

DOI: dx.doi.org/10.30525/978-9934-571-30-5_20

Abstract. In the article the author examines the National Bank of Ukraine, private and commercial banks, the world in general and the entire Ukrainian banking system is not working on Ukraine's economy, and the economies of other countries and serves the interests of political clans and oligarchs. Society is at the beginning of the rapid urbanization of cities, nanotechnology boom, cyborgization neural interfaces, merger of biological and digital intelligence as important today determine trends in the development of future technologies, such as electronic money (crypto currency) as an important segment of the financial market, its transformation and reorientation in terms automation and global information society. Everything that can be digitized will be digitized, so financiers will go to the background. Who will control the banking financial algorithms of the NBU, will it perform a genuine regulator function, work for the people of Ukraine, or even more usurp financially - monetary power against people. The main question is whether the NBU and the commercial banks of the people of Ukraine in this format are needed or not. The theoretical basis for the study was the scientific works of domestic and foreign scientists in the field of the world economy, financial globalization, the development of the financial system and international financial centers (MFCs), the impact of the global financial crisis on the MFC and its manifestations in financial centers. This issue is dealt with in the works of such scholars as L. Krasavina, Y. Makogon, G. Muzychenko,

\footnotetext{
${ }^{1}$ Candidate of Public Administration,

Senior Lecturer at Department of Public Management and Administration, Vice Rector for Scientific Affairs,

Ukrainian State Employment Service Training Institute, Ukraine

(C) Marianenko Gennadiy
} 
O. Rogach, L. Shpak, and others. The purpose of this work is to find out the main goals, tasks and tasks of the Central Bank. Elimination of the National Bank of Ukraine as a criminal system for theft of the Ukrainian people, an instrument for enriching the oligarchs and the political elite, financing the party system, converting and withdrawing money abroad to offshore zones, which resulted in the destruction of the economy and independence of our state. The introduction of a new National Banking Financial System is really relevant to the protection and development of the welfare of the people of Ukraine in the direction of the monetary market, the mastery of the latest monetary instruments, given that in the future everything that can be digitized will be digitized. Therefore, today it is necessary to understand that the use of banknotes and the existing banking system is the past, there is a new era of electronic money - crypto-currency (bitokin, etc.). We do not know in what format it will be final, but for sure. Therefore, we must develop and implement a truly national National Banking System.

\section{1. Вступ}

Національний банк України є центральним банком України, особливим центральним органом державного управління, юридичний статус, завдання, функції, повноваження і принципи організації якого визначаються Конституцією України та іншими законами.

3 моменту, коли Україна стала незалежною державою, Національний банк України, приватні банки та взагалі вся українська банківська система працювала не на економіку України, а на економіку інших країн і таким чином зробила все можливе, щоб знецінити власну грошову одиницю і взагалі знищити українську валюту. Так, встановивши ставку по гривневих кредитах більшу на 100\%, ніж ставка по доларових кредитах, Національний банк України тим самим заклав основу для підвищення інфляції, знецінення гривні та для майбутнього дефолту. Оскільки відсоток за користування доларовими кредитами був у 2 рази менший, ніж відсоток по кредитах у гривні, громадянам було вигідніше брати доларові кредити, що масово і відбувалося. Але навіщо банкам взагалі надавати населенню кредити в доларах, якщо в Україні законодавчо заборонено розраховуватись за товари чи послуги іноземною валютою? Відповідь одна - для того, щоб знищити українську гривню i грабувати народ, для того щоб створити сотні тисяч пунктів по обміну валюти і через них «відмивати» гроші, вкрадені з бюджету. 


\section{2. Характеристика діяльності \\ Національної банківської системи України}

Найбільші Українські банки, котрі належали народу, вже давно не $є$ Українськими, а продані іноземним фінансових групам (французьким, німецьким, італійським та ін.) та мають доступ до відносно дешевих валютних ресурсів. Використовуючи дешеві фінансові ресурси, отримані від «батьківських» іноземних закордонних груп, Українські банки надавали громадянам кредити в доларах та євро вже за своєю, набагато підвищеною ставкою [4].

Банкам взагалі все одно, підвищується курс долара чи зменшується, вони свій прибуток з народної кишені отримають у будь-якому випадку. Банки самі встановлюють курс долара до гривні, і купити цей долар можна тільки у банка. Громадяни отримують зарплату в гривнях. Таким чином, якщо громадянин взяв доларовий кредит в банку, то для того, щоб повернути кредит, йому необхідно продати гривню (за курсом, який встановлюють тільки банки) та купити долари, які він потім банку і віддасть. Але долар він може отримати тільки в банку і по ціні, яку йому запропонують банкіри [4].

Таким чином, надаючи кредити в доларах при забороні розрахунків у валюті, банки шляхом встановлення обмінного курсу долара до гривні самі визначають, скільки людина повинна віддати їм кровно зароблених гривень для того, щоб повернути доларовий кредит.

Інституції публічного управління повинні негайно дослідити та проаналізувати діяльність Національного банку України, приватні та комерційні банки, взагалі всю світову та українську банківську систему, яка працює не на економіку України, а на економіку інших країн та обслуговує інтереси політичних кланів та олігархів. Суспільство знаходиться на початку самої швидкої урбанізації міст, нанотехнологічного буму, кіборгізації нейроінтерфейсів, симбіозу біологічного та цифрового інтелекту, тому важливе сьогоднішне визначення тенденцій розвитку майбутніх технологій, а саме електронних грошів (криптовалюти) як важливого сегменту фінансового ринку, його трансформації та переорієнтації в умовах глобальної автоматизації та інформатизації суспільства. Все, що може бути оцифроване, буде оцифроване, тому фінансисти підуть на задній план. Хто буде контролювати банківські фінансові алгоритми Національного банку України, буде він виконувати дійсну функцію регулятора, працювати на народ 
України, чи ще більш узурпує фінансово-грошову владу проти людей. Головне питання чи потрібен Національний банк України та комерційні банки народу України в такому форматі, чи ні [7].

\section{3. Сутність Національного банку України}

Національний банк України є особливим центральним органом державного управління, іiі емісійним центром, проводить єдину державну політику в галузі грошового обігу, кредиту, зміцнення грошової одиниці, організує міжбанківські розрахунки, координує діяльність банківської системи в цілому, визначає курс грошової одиниці відносно валют інших країн. Національний банк визначає вид грошових знаків, їх номінал, відмінні ознаки і систему захисту. Національний банк України зберігає резервні фонди грошових знаків, дорогоцінні метали та золотовалютні запаси, накопичує золотовалютні резерви і здійснює операції з ними та банківськими металами. Національний банк України встановлює порядок визначення облікової ставки та інших процентних ставок за своїми операціями, дає дозвіл на створення комерційних банків шляхом їх реєстрації та видає ліцензії на виконання банківських операцій, встановлює банкам та іншим фінансово-кредитним установам нормативи обов'язкового резервування коштів [5].

Це одна сторона медалі яка призначена для споглядання народом України, а насправді що в місії Національного банку України відповідає національним інтересам, спробуємо розібратися.

Національний банк подає звітність та надає інформацію органам державної влади та іншим державним органам у випадках, передбачених Конституцією України та Законом. Законодавче регулювання питань, пов'язаних з виконанням Національним банком своїх функцій, здійснюється шляхом внесення змін до цього Закону [5].

Не допускається втручання органів державної влади та інших державних органів чи їх посадових та службових осіб, будь-яких юридичних чи фізичних осіб у виконання функцій і повноважень Національного банку, Ради Національного банку, Правління Національного банку чи службовців Національного банку інакше, як в межах, визначених Конституцією України та Законом. Федеральна резервна система також не підзвітна нікому. Вона не має бюджету, не піддається аудиторським перевіркам, жоден комітет Конгресу не знає про ії операціях 
і не може їх контролювати. Федеральний резерв, фактично повністю контролює грошову систему країни, ні перед ким не звітує, причому таке дивне положення справ підноситься як якесь благо [7].

Не допускається використання золотовалютного резерву для надання кредитів і гарантій та інших зобов'язань резидентам і нерезидентам України. Так для чого ж нам потрібний золотий запас, якщо він не використовується для збільшення грошової маси усередині країни, товарообігу, кредитування виробництва і населення передусім в інтересах українського народу? Або конкретне питання, а чи є він взагалі, хто його бачив, чи $\epsilon$ відео у присутності преси в сховищі, як наприклад у сховищі Федеральної резервної системі (далі- ФРС) ОАС. А в нас це проблема, табу за сьома замками [6].

Позичковий відсоток який впроваджений в державність України, облікова ставка Національного Банку України (далі - НБУ) 3 13.06.2013 - 6,5\% Постанова НБУ від 12.06.2013, з 14.04.2017 - 14\% Постанова № 209. ФРС США кредитує під 0,5\% і держава може брати кредити у ФРС, а держава Україна в своєму Національному банку такої можливості немає. НБУ функціонує як ларьок з обміну валюти відповідно системі для країн третього світу Карренсі борд - це пряме відповідність всієї грошової маси в Україні ії валютні резерви, а саме в доларах, євро і т.д. Але гроші - долари від ФРС, МВФ і Світового банку, це рядок з деякою кількістю нулів в рядку комп'ютера i все, іноді коли потрібна готівка, банкноти друкують і привозять в нашу країну, після чого їх безперешкодно скуповують олігархи через біржу, в тому числі у населення через обмінні пункти [4].

\section{4. Поточний стан речей діяльності Національного банку України.}

Давайте встановимо справжній стан речей, щодо поточного стану Національного банку України, для чого ця структура була створена, i iii вплив на державу Україна.

Національний банк України, не є структурою, яка діє в національних інтересах України, а є філією Федеральної Резервної Системи США, (приватної корпорації, яка емітує долар) - яке так само відноситься i до ситуації з Центробанком Російської Федерації. Центральний банк майже життєво необхідний для процвітання комерційних банків, для їх професійної діяльності в якості виробників нових грошей за допомогою випуску ілюзорних складських розписок на стандартну готівку [7]. 
НБУ не діє в національних інтересах України, і виконавча влада не має достатніх важелів для впливу на НБУ. Статті законів про НБУ, вимагають роз'яснення. Наприклад, стаття 54 закону України «Про Національний банк України» говорить, що Національний банк не має права надавати кредити в національній та іноземній Валюті, як прямо, так и опосередковано через державну установу, іншім юридичним особам, майно якої перебуває у державній власності за, на фінансування витрат Державного бюджету України. Національний банк не має права купувати на первинному Сайті всі цінні папери, емітовані Кабінетом Міністрів України, державною установою, іншою юридичною особою, майно якої перебуває у державній власності [5].

Що це за держбанк, який не кредитує свою державу і програми 3 розвитку держави Україна? У відповідності з конституцією України ми маємо грошові знаки, а за фактом розписки банку - банкноти, які нічим не підкріплені. В статті 53 вказаного закону зазначається, що не допускається втручання органів державної влади та інших державних органів чи їх посадових та службових осіб, будь-яких юридичних чи фізичних осіб у виконання функцій і повноважень Національного банку, Ради Національного банку, Правління Національного банку чи службовців Національного банку інакше, як в межах, визначених Конституцією України та цим Законом. Національний банк подає звітність та надає інформацію органам державної влади та іншим державним органам у випадках, передбачених Конституцією України та цим Законом [5].

Законодавче регулювання питань, пов'язаних з виконанням Національним банком своїх функцій, здійснюється шляхом внесення змін до цього Закону.

В статті 48 закону вказується, що не допускається використання золотовалютного резерву для надання кредитів і гарантій та інших зобов'язань резидентам і нерезидентам України. Так для чого ж нам потрібний золотий запас, якщо він не використовується для збільшення грошової маси усередині країни, товарообігу, кредитування виробництва і населення, передусім в інтересах українського народу, чи є він взагалі? [5].

У сучасному світі, коли інтернет технологіями вже нікого не здивуєш, а платежі через інтернет проводить кожен другий, все частіше звучить термін «крипто валюта». Що це таке, ми і спробуємо розібратися. 


\section{Chapter 11. State administration}

\section{5. Визначення криптовалюти}

Криптовалюта - від англійського “cryptocurrency", тобто віртуальна валюта, захищена криптографією. В першу чергу, криптовалюта - це швидка і надійна система платежів і грошових переказів, грунтована на новітніх технологіях і непідконтрольна жодному уряду. У світі зараз досить багато криптовалют (Bitcoin, Litecoin, Ethereum, Peercoin), але найвідомішою і такою, що швидко розвивається є - Bitcoin (Біткоін). У 2015 році Свропейський суд звільнив Bitcoin від оподаткування, чим фактично визнав ії̈ повноцінною грошовою одиницею [1].

Що ж це таке і як застосувати віртуальні гроші в нашому житті?

Криптовалюта - це цифрова валюта, яка має зашифрований код. При розшифровці даного коду з'являється монета, яка може бути використана для платежів. Регулятори зробили кроки для зміцнення світової фінансової системи, за вісім років після колапсу. Але цього не достатньо - нові технології можуть підвищити стійкість світової фінансової системи. До цих технологій і відноситься блокчейн - ключова для криптовалюти [1].

На даний момент фінансова система нестійка і слабка, тому що недокапіталізовані банки та інші централізовані хаби контролюють платежі і трейдинг - ключові функції фінансової системи. Збитки таких хабів миттєво поширюються на всю економіку, незважаючи на всі зусилля регуляторів. Регулятори працюють наосліп, а це ще гірше. У них немає можливості оцінювати ситуацію в режимі реального часу і розуміти, де саме виникають ризики. Обидві проблеми здатний вирішити блокчейн [1].

Довіра є головною властивістю фінансової системи. Вона необхідна для того, щоб проводити платежі між незнайомцями. Що кому належить, і хто кому винен - на ці питання фінансові установи знайшли відповіді різними способами. Але при цьому, фінансові установи стали центрами уразливості системи.

Блокчейн забезпечує довіру наступним чином: система створює розподілений реєстр, в якому є записи про всі транзакції учасників системи. Блокчейн підтверджує транзакції і записує мережу з мільйонів комп'ютерів у всьому світі. Тому, потреба довіряти єдиному джерелу виключається. Інформація розподіляється і зберігається на такій величезній кількості носіїв, що питання ії достовірності та збереження смішно навіть обговорювати. Тепер залишається тільки уявити такий 
розподілений реєстр із записами про всі транзакції світу. Це дозволить кому завгодно стежити за системою і виявляти ризики в режимі реального часу. Також регулятору не доведеться замислюватися над забезпеченням транзакцій, якщо у системного банку виникнуть проблеми. Можна перераховувати ще багато переваг системи Блокчейн, але вже і так зрозуміло, що в підсумку фінансове регулювання стане набагато простіше [1].

Таким чином, можна зробити висновок, що криптовалюта - це гроші майбутнього!

\section{6. Запровадження нової}

\section{Національної банківської фінансової системи України}

Щодо України, то у нас по суті та сама проблема, що й у більш цивілізованих країн, технології випереджають законодавство. Проблема одна, підходи до вирішення різні. Згідно із Законом «Про платіжні системи та переказ коштів в Україні» електронні гроші - це одиниці вартості, що зберігаються на електронному пристрої, приймаються як засіб платежу іншими особами, аніж тим хто їх випускає, і є грошовим зобов'язанням у готівковій або безготівковій формі. Випуск електронних грошей може здійснювати виключно банк, на якого покладаються обов'язки з їх погашення. Через свої технології Bitcoin не потрапляє під українське визначення поняття «електронні гроші», оскільки не містить зобов'язання емітента 3 його погашення, не має єдиного емісійного центру, і не прив'язаний до жодних готівкових або безготівкових коштів. У свою чергу «безготівкові кошти» за українським законодавством можуть існувати виключно у формі записів на банківських рахунках. Банки не беруть участі у процесі емісії та обігу криптовалют, тому Bitcoin не може вважатись «коштами». Не потрапляє Bitcoin і під визначення «платіжної системи», оскільки основною та обов'язковою функцією, платіжної системи є проведення переказу грошових коштів [1].

Той хто контролює гроші, контролює світ і розвиток суспільства, таких людей дуже небагато. Ми дозволили їм незліченні багатства, так до чого ж вони прагнуть, яка їхня мета. Секретна мета - повне світове панування.

Вони вже контролюють:

- гроші; 


\section{Chapter 11. State administration}

- воду;

- енергію (стримують розвиток альтернативних джерел енергіi);

- сільське господарство;

- охорону здоров'я (не даючи розвивати альтернативні методи лікування);

- інформацію і нашу реакцію на їі отримання;

- шпигують за громадянами, відстежують всі сторони нашого життя;

Взагалі у них все готово для того щоб правити світом [4].

Сьогодні необхідно розробити державні механізми запровадження ліквідації Національного банку України як злочинної системи обкрадання Українського народу, інструменту збагачення олігархів і політичної еліти, фінансування партійної системи, конвертації та виведення грошей за кордон до офшорних зон, внаслідок чого знищено економіку та незалежність нашої держави. Запровадження нової Національної банківської фінансової системи дійсно відповідної до захисту та розвитку добробуту народу України у напрямі управління грошово-кредитним ринком, опанування новітніх монетарних інструментів, враховуючи що у майбутньому все що може бути оцифровано, буде оцифровано. Тому вже сьогодні необхідно зрозуміти що застосування банкнот та існуюча банківська система це минуле, наступає нова ера електронних грошей - криптовалюта (біткоін та ін.) Ми не знаємо в якому форматі це буде остаточно, але напевно. Тому публічне управління державою повинно розробити та запровадити дійсно народну Національну банківську систему [7].

Якщо ми не зрозуміємо, що відбувається, нас чекає диктатура військових, все буде зосереджено в руках «жменьки» жадібних людей.

Вони вже почали втілювати свій план, вони поділили світ на супер об'єкти - Свропейський Союз, Африканський Союз, працюють над створенням Американського і Тихоокеанского Союзу, в період кризи створений G20. Війна у Сирії та на Сході України [4].

Золотий запас України станом на 2017 рік становив 26 тонн. Після глобального розпродажу резерву в середині осені, вже до кінця року в 3МІ з'явилася інформація про те, що резервному банку все-таки вдалося трохи наростити капітал. За офіційними даними, до кінця січня 2015 року, обсяг золота країни склав близько 0770000 тройських унцій проти грудневого показника в 0760000 тройських унцій. Можна ска- 


\section{Marianenko Gennadiy}

зати й про те, що в доларовому еквіваленті українські запаси золота в січні 2015 виросли з 911,09 до 967250000 доларів. Золотовалютний запас продовжує скорочуватися швидкими темпами. Це пов'язано 3 тим, що транші від МВФ були затримані, при цьому необхідність оплачувати зовнішні борги і газ в зимовий період збереглася [2].

Президент України Петро Порошенко під час п'ятого засідання Ради регіонального розвитку у Києві, повідомляє «Укрінформ»: «Золотовалютні резерви танули наче сніг навесні, і на лютий 2015 року всохли практично до \$5 млрд. Сьогодні вони становлять \$15,5 мільярда», - сказав він. Я думаю що пересічній громадянин не розуміє такого росту ЗВР у 2015 було 26 тон 967 млрд, у 2017 році стало - 15.5 млрд, при тому що за саме золото мовчать, річ йде лише про валюту (строка з нулями у комп'ютері), де золото нації ? У 2014 було 42,61 тонн золота! [3].

Україна займає 53 місто у світі по кількості золота, яке зберігається в державних резервах. В 2014 році золотий запас України значно знизився - більш ніж на 19,01 тонн. На початок 2017 року, золотий резерв центрального банку України має об'єм - 25,5 тонн [3] (рис. 1).

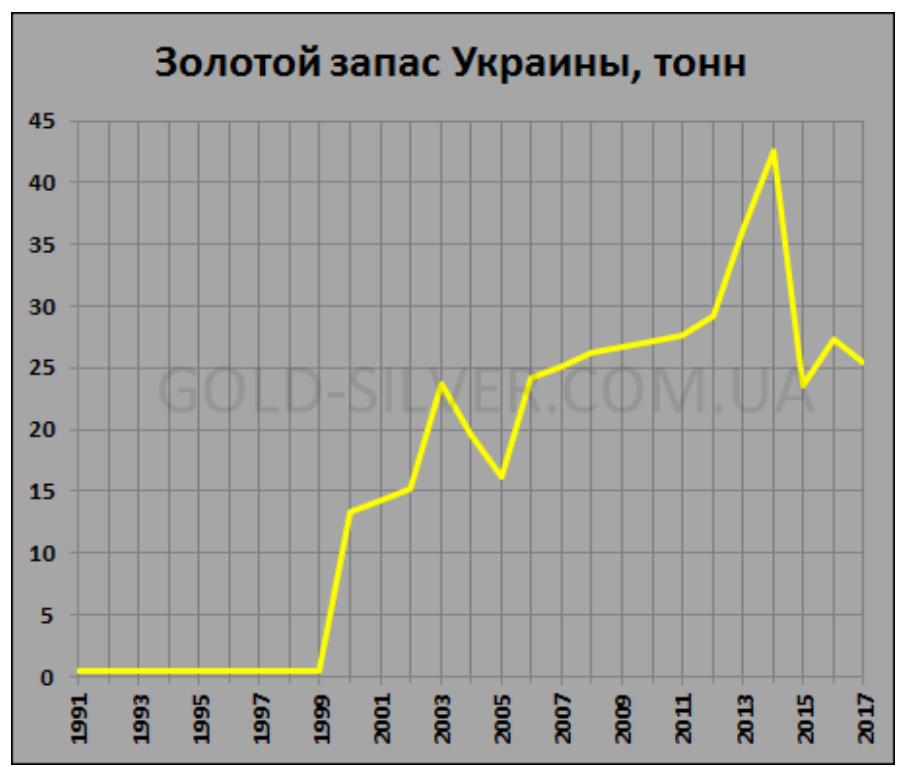

Рис. 1. 
Офіційні міжнародні резерви України в 2018 р. (млн. дол. США)

\begin{tabular}{|c|c|c|c|}
\hline \multicolumn{3}{|c|}{ Офіційні міжнародні резерви України в 2018 р. (млн. дол. США) } \\
\hline на 31.12 .2017 & 18808,45 & -122.61 & $-0.65 \%$ \\
\hline на 31.01 .2018 & 18580,34 & -228.11 & $-1.21 \%$ \\
\hline на 28.02.2018 & 18410,28 & -170.06 & $-0.92 \%$ \\
\hline на 31.03.2018 & 18191,90 & -218.38 & $-1.19 \%$ \\
\hline на 30.04.2018 & 18421,48 & 229.58 & $1.26 \%$ \\
\hline
\end{tabular}

Джерело: за інформачією МВФ та НБУ

Таблиця 2

\section{Золотий запас України}

\begin{tabular}{|c|c|c|c|}
\hline \multicolumn{4}{|c|}{ Золотий запас України } \\
\hline Рік & Тонн & Рік & Тонн \\
\hline 1991 & 0 & 2005 & 16,17 \\
\hline 1992 & 0 & 2006 & 24,26 \\
\hline 1993 & 0 & 2007 & 25,19 \\
\hline 1994 & 0 & 2008 & 26,16 \\
\hline 1995 & 0 & 2009 & 26,69 \\
\hline 1996 & 0 & 2010 & 27,15 \\
\hline 1997 & 0 & 2011 & 27,65 \\
\hline 1998 & 0 & 2012 & 29,21 \\
\hline 1999 & 0 & 2013 & 36,08 \\
\hline 2000 & 13,4 & 2014 & 42,61 \\
\hline 2001 & 14,3 & 2015 & 23,6 \\
\hline 2002 & 15,19 & 2016 & 27,37 \\
\hline 2003 & 23,64 & 2017 & 25,5 \\
\hline 2004 & 19,6 & \multicolumn{2}{c}{}
\end{tabular}

Президент наголосив, що кредити від МВФ пішли саме у золотовалютні резерви країни. Продовжується практика поневолення держав кредитною політикою МВФ та Світового банку, розкрадання та вивезення природніх ресурсів.Це про світову банківську систему, а що стосується нас українців безпосередньо? Якщо розглядати світову фінансову систему як колоду гральних карт, то наші комерційні банки в ній - шістки, а НБУ - козирна шістка. Передумовою успішного функціонування банківської системи будь-якого суспільства є довіра громадян! 
Ми стверджуємо, що НБУ і банківську комерційну систему необхідно ліквідувати, в такому вигляді вона не потрібна! Ми ні в якому разі не закликаємо до знищення приватної власності, але в даному випадку нехай банкіри та олігархи вкладають свої особисті гроші в депозит державних банків, а не ризикують депозитами вкладників в своїх приватних банках застосовуючи схему часткового резервування. Як показує практика частіше банкіри безкарно розкрадають гроші вкладників, НБУ як регулятор стоїть на сторожі інтересів злодіїв-банкірів, а не народу України, покриваються і виплачуються колосальні мільярдні суми 3 кишені платників податків на покриття збитків в результаті виведення капіталу в офшори, фіктивне банкрутство, коли виявляється, що в активі банку значиться письмовий стіл та шарикова ручка, та інші схеми. А що робиться з безпекою та охороною інформації, олігархи та політична еліта маючи доступ до операцій та коливань курсу валют через НБУ, кожного дня заробляють мільйони на курсовій різниці, хто і коли буде відповідати за розпад економічного потенціалу держави, за злочини проти свого народу?!

Гроші - це один із стовпів нашої цивілізації. Але користуючись ними кожного дня, більшість із нас до кінця не знає, що таке гроші. За звичними для нас лаштунками купюр, банківських рахунків та курсів валют залишається неймовірно складна система інституцій, процесів, взаємозв'язків, що діють за своїми законами.

Відтоді, як Бреттон-Вудська система себе вичерпала у середині 70-х рр. минулого століття, балом заправляють фіатні гроші. Фіатні гроші - це законні платіжні засоби, номінальна вартість яких встановлюється, забезпечується і гарантується державою за допомогою ії авторитету і влади, і які не мають жодної самостійної вартості [4]. Тобто гроші давно стали абстрактним математичним вираженням вартості, а інформаційні технології вивели цю абстрактність на новий рівень. Більшість розрахунків у світі відбуваються у безготівковій формі - це трильйонні суми різних грошей, які щодня змінюють мільярди рук просто у вигляді цифр на екрані комп'ютера. Але поряд з консервативними електронними засобами, особливої уваги заслуговують криптовалюти. На запитання, що таке криптовалюта, ви частіше за все почуєте відповідь, що це - електронні гроші. На перший погляд, можливо так, але ближче знайомство із криптовалютами показує, наскільки насправді це поверхове судження [1]. 


\section{Chapter 11. State administration}

У будь-якому разі криптовалюти - це перспективна технологія, i вона буде розвиватись, незважаючи на спротив чи нерозуміння. Кількість людей, які довіряють криптовалютам постійно зростає, так само як і кількість тих, для кого це стало серйозним бізнесом. Правда, український чиновник ще не готовий до таких речей через видові особливості психіки. Адже навіть на цьому етапі розвитку криптовалюти можуть скласти конкуренцію національній валюті щодо надійності чи навіть міжнародної валютної ліквідності.

У світі більшість фінансових та банківських алгоритмів вже обчислюється комп'ютерами та роботами, банк майбутнього-це величезний банкомат без персоналу [7]. На сьогоднішній день ефективність праці банківського персоналу поки що орієнтується саме на людський фактор, а не на можливість сучасних технологій, але ми розуміємо, що це не на довго. Ми вже сьогодні повинні зрозуміти, що ставлення до людських ресурсів у майбутньому забезпеченні якості банківських продуктів буде значно знижено, прибутковість діяльності банку у зв'язку скороченням витрат на утримання персоналу швидко і безконтрольно буде зростати. При таких умовах позичковий відсоток, облікова ставка повинна суттєво зменшитись, але ми розуміємо, що банкіри самі цього не зроблять, лише будуть далі збагачуватись за рахунок українців.

Проблема золотовалютного резерву (далі - ЗВР), як його формувати, за рахунок чого? Якщо ми розуміємо необхідність та прагнемо запровадження дійсно народної банківської системи, чому народ України не може бути співвласником ЗВР, та акціонером національного банку. Суспільство має у власності не тільки валюту, а й золото у величезному тоннажі та еквіваленті тройських унцій. Наприклад, будь-який громадянин нашої країни може своєю часткою формувати ЗВР та отримувати дивіденди, при чому йому не має необхідності на відмінність від валюти здавати його, лише зареєструвати без права вивозу за кордон.

Вклади та депозити, нехай банкіри та олігархи вкладають свої особисті гроші в депозит державних банків, а не ризикують депозитами вкладників в своїх приватно-комерційних банках, застосовуючи схему часткового резервування та запланованого розкрадання. Генрі Форд казав: «Добре, що люди нашої країни не розуміють нашу банківську і валютну системи. Якби вони в них розбиралися, вже завтра вранці почалася б революція». Тепер має бути абсолютно ясно, що ми не 
можемо розраховувати на Національний банк України, МВФ, Світовий Банк, Федеральний резерв США, що вони будуть вести боротьбу проти хронічної інфляції, яка погубила наші заощадження, знівечила нашу валюту, здійснила прихований перерозподіл доходів і багатства і принесла з собою руйнівні економічні буми і кризи. Всупереч пропаганді істеблішменту та нашої політичної еліти, НБУ, Федеральний резерв і приватні комерційні банки не $\epsilon$ «інфляційними яструбами», як вони люблять себе називати. Федеральний резерв і банки не є частиною вирішення проблеми інфляції, навпаки, вони $є$ частиною проблеми. Фактично, вони і $є$ сама проблема. Світова й наша економіка страждає від хронічної інфляції, від руйнівних бумів і кризи, тому що інфляція безперервно породжується сам Федеральний резерв та його філії МВФ, НБУ. Ця роль, по суті, і є метою їх існування: об'єднати приватні комерційні банки в картель і допомогти їм розв'язати інфляцію грошей і кредиту, накачуючи резерви в банки і надаючи їм фінансову допомогу, коли вони потрапляють у «важкі» ситуації [7].

\section{7. Висновки}

Гроші - умовний еквівалент кількості продуктивної праці. Людина працює: витрачає свій час, енергію, здоров'я, застосовує знання, досвід, кваліфікацію і отримує за роботу зарплату. Суспільство доручає і довіряє політикам та НБУ у владі продукувати гроші і здійснювати їх емісію. Нікому в Світі не дано право відбирати у нас результати нашої праці, тобто зароблені нами гроші і майно належить народу України, тому наш головний обов'язок інституції публічного управління забезпечити збереження результатів праці, майна, грошей кожного громадянина України.

\section{Список літератури:}

1. Поливка Н. Криптовалюти і «різноманітні біткоіни» / Юридична газета // [Електронний ресурс]. - Режим доступу: http://yur-gazeta.com/ publications/practice/informaciyne-pravo-telekomunikaciyi/kriptovalyuti-iriznomanitni-bitkoini.html. - Назва з екрана.

2. Золотий запас України. Золотовалютні резерви України [Електронний pecypc]. - Режим доступу: http://faqukr.ru/novini-ta-suspilstvo/60253-zolotijzapas-ukraini-zolotovaljutni-rezervi.html - Назва з екрана.

3. Золотовалютні резерви України за два роки зросли до $\$ 15,5$ млрд [Електронний ресурс]. - Режим доступу: https://zik.ua/news/2017/03/20/ zolotovalyutni_rezervy_ukrainy_za_dva_roky_zrosly_do_155_mlrd_1063889 Назва $з$ екрана̄. 


\section{Chapter 11. State administration}

4. Данилишин Б. Співробітництво з МВФ: проблеми і перспективи / Дзеркало тижня // [Електронний ресурс]. - Режим доступу: https://dt.ua/ macrolevel/ spivrobitnictvo-z-mvf-problemi-i-perspektivi-_.html-Назва з екрана.

5. Про Національний банк України: закон України від 20.05.1999 № 679-XIV [Електронний ресурс]. - Режим доступу: http://zakon0.rada.gov.ua/ laws/show/679-14 - Назва з екрана.

6. Ротбард М. Показання проти Федерального резерву / пер. $з$ англ. під ред. А. В. Куряева. - Челябінськ: Соціум, 2003. - 183 с.

7. Всесвітній економічний форум (World Economic Forum) [Електронний pecypc]. - Режим доступу: https://www.weforum.org/events/world-economicforum-annual-meeting-2018 - Назва з екрана.

\section{References:}

1. Polyvka, N. (2015), Cripples and "various bitcoins", Yurydychna hazeta, [Online], available at: http://yur-gazeta.com/publications/practice/informaciynepravo-telekomunikaciyi/kriptovalyuti-i-riznomanitni-bitkoini.html (Accessed 11 Jun 2015).

2. Gold reserve of Ukraine. Gold and foreign exchange reserves of Ukraine (2015), available at: http://faqukr.ru/novini-ta-suspilstvo/60253-zolotij-zapasukraini-zolotovaljutni-rezervi.html (Accessed 3 Jul 2018).

3 . Gold and foreign exchange reserves of Ukraine over two years increased to \$ 15.5 billion (2017), available at: https://zik.ua/news/2017/03/20/zolotovalyutni rezervy_ukrainy_za_dva_roky_zrosly_do_155_mlrd_1063889 (Accessed 20 Mar 2017).

4. Danylyshyn B. (2016), Cooperation with the IMF: problems and prospects, Dzerkalo tyzhnia, [Online], available at: https://dt.ua/macrolevel/spivrobitnictvo-zmvf-problemi-i-perspektivi-_html (Accessed 25 Nov 2016).

5. The Verkhovna Rada of Ukraine (1999), The Law of Ukraine "The National Bank of Ukraine", available at: http://zakon0.rada.gov.ua/laws/show/679-14 (Accessed 3 Jul 2018).

6. Rotbard, M. (2003), Pokazannia proty Federal'noho rezervu [Indications against the Federal Reserve], Cheliabins'k: Sotsium.

7. The official site of World Economic Forum (2018), World Economic Forum Annual Meeting, available at: https://www.weforum.org/events/world-economicforum-annual-meeting-2018 (Accessed 3 Jul 2018). 